\title{
Daniel W. Brown A New Introduction to Islam, 2nd ed.
}

West Sussex, UK: Wiley-Blackwell, 2009.pbk. 339 pages

A New Introduction to Islam is an excellent undergraduate textbook presenting a thorough history of Islam. It introduces students to the history and development of Islamic studies as a discipline-showing how Islamic studies has shaped our understanding of Islam - and it also examines how the vibrant religious culture of the Near East produced a unique and brilliant intellectual and religious tradition spanning the fields of Islamic law, theology, philosophy, and mysticism. In addition, it shows the ways in which the Islamic tradition has enriched the world, and in turn, how it has been enriched by interaction with other civilizations. And against the background of social and cultural contexts that extend from North Africa to South and Southeast Asia, it also considers the opportunities and challenges facing Muslims today and provides a new and illuminating perspective of the development of Muslim beliefs and practices.

The book consists of four parts (with seventeen chapters): Part 1, "The Formation of the Islamic Tradition" (six chapters); Part 2, "The Expansion of Islam" (three chapters); Part 3, "Islamic Institutions" (three chapters); and Part 4, "Crisis and Renewal in Islamic History" (five chapters). These parts are preceded by a list of illustrations (thirty-three diagrams and pictures and seven maps), a preface to the second edition, source acknowledgments, a glossary, a bibliography, and an index.

Part 1, "The Formation of the Islamic Tradition," explores the historical and religious context of the rise of Islam, and provides a survey of the central elements of the Islamic tradition. Beginning with Pre-Islamic Arabia, it immediately raises the critical questions, such as: "How significant is the Arab background for understanding the rise of Islam?" and "Is sixthcentury Arabia a credible context for the rise of a new, vigorous monotheistic faith and a vibrant civilization?" (See 15.) These questions are answered in Chapter 3, which provides an exploration of Near Eastern civilization and religion before the rise of Islam, and Chapter 4 (which examines the sacred history of Islam, beginning with the key narrative in that history, the life of Muhammad [pbuh]). Chapters 5 and 6 discuss how the Qur'an came into its present form, and the authenticity of the Hadith literature. Here, Brown contends that with two centuries of "critical scholarship" have increasingly brought into question the traditional account of how Islam came into being. For him: 
- the Qur`an is largely "inaccessible," because its "narratives are allusive," "constructions devoid of context," and much "vocabulary opaque" (86)

- $\quad$ and the Islamic tradition was not fully formed but "grew, took root, and flourished over the course of several turbulent centuries" (100)

In Part 2, "The Expansion of Islam," the focus is turned from sacred history and the formative elements of Islam to the "complex historical context" beginning with the Arab conquests, in which Islamic civilization grew to maturity. Chapter 8 examines the worldview of the early Arab conquerors. The focus of this chapter is how Arab identity combined with Near Eastern patterns of religious life to form something completely new. Finally, in Chapter 9, the focus is on the history (from the rise of the Abbasid caliphate) of the maturing of Islamic political thought and the emergence of the major schisms in Islam.

Part 3, "Islamic Institutions," surveys the great institutions of Islamic civilization in their maturity: Islamic law; Islamic theology, and Islamic philosophy - and Sufism (the "spiritual center" of Islam). The elucidation of Islamic law (Shar'iah) preoccupied the greatest minds of the Islamic world, and the resulting system was a signature achievement of Islamic civilization, and the ideals of Islamic law continued to give the Islamic world unity and coherence long after it had fragmented politically. These three great institutions - the law, theology and philosophy-and Sufism are the defining features of Islam in its maturity, the characteristics that gave it the coherence, the brilliance, and the resiliency that marked Islamic civilization at its height.

Part 4, "Crisis and Renewal in Islamic History." Its five chapters examine Muslim responses to the challenge of history and the patterns of renewal and reform in Islam. The ways in which Muslims met the challenges of the Crusades and the Mongol invasions are both of intrinsic interest and are harbingers for understanding of what would follow. What did follow was first of all a blossoming of great Islamic empires on the eve of modernity. The sixteenth century Muslims witnessed a complete redrawing of the map of their world with the rise of "three great empires" - the Ottoman, the Safavid, and the Mughal-all rooted in the "Mongol-Turkish synthesis," and the masterpieces of these empires are still visible in the architectural treasures of Istanbul, Isfahan, Agra, and Lahore (234). From the eighteenth century onwards, the power and pervasiveness of Western civilization has proved to be a challenge in Islamic history. 
In Chapter 16, "The Turbulent Twentieth Century," the author adopts a "different approach," and that approach is the focus on the question "What is it that Muslims are responding to?" "What changes has the modern world brought to Islam in each of the classical Islamic institutions: political institutions, Islamic law, theology, and Sufism?" "How has each of these institutions fared in the modern world?" and "What has changed, and what has remained the same/unchanged?" (260). In this chapter, the author maintains that the "major institutions and intellectual traditions" of Islam have shown "remarkable resilience" in the face of the "challenge of modernity" (280). For Brown, Islamic political thought, legal ideas, and theological speculation have all demonstrated a "surprising vitality" (ibid.).

The concluding chapter (Chapter 17), "Islam in the Twenty-First Century," surveys the most important currents in recent Islamic thought (the discussions on major challenges facing Muslims in the twenty-first century): the challenge of pluralism, Islamic liberalism, Islam in the West, Islamic feminism. For Brown, the most urgent set of "theological, ethical and political problems" faced by the Muslim community in the contemporary world is posed by the "challenge of pluralism" (283)

A New Introduction to Islam is one of the most lucidly organized introductions to Islam; it is informative and clear on all the major issues and historical events pertaining to Islam, and it is also a thoughtful and a comprehensive guide to the study of the materials and the ways of thinking about Islam. The book is up-to-date-not only in its discussion of issues like "Islam and Modernity" but also in bringing up recent scholarly debates about the Qur`an and Islamic traditions. 